\title{
IMPLEMENTASI UNDANG-UNDANG NOMOR 35 TAHUN 2014 TERHADAP PENCEGAHAN KEKERASAN ANAK DI MASA PANDEMI COVID-19 DI DESA BRENGKOK KABUPATEN LAMONGAN
}

\author{
Ilya Syafa'atun Ni'mah \\ Institut Agama Islam Negeri (IAIN) Kediri \\ ilyasyafanie20@gmail.com \\ Dijan Novia Saka \\ Institut Agama Islam Negeri (IAIN) Kediri \\ ajisakanova@gmail.com \\ Fatimatuz Zahro \\ Institut Agama Islam Negeri (IAIN) Kediri \\ fatimatuz.zahro1305@gmail.com
}

\begin{abstract}
Abstrak:
Tujuan dari penelitian ini yaitu untuk mengetahui faktor penyebab terjadinya kekerasan pada anak dimasa pandemi Covid-19 dan bagaimana upaya pencegahan serta implementasinya berdasarkan Undang-Undang Nomor 35 Tahun 2014. Penelitian ini menggunakan metode penelitian kualitatif deskriptif dengan jenis penelitian lapangan (field research) yang menggunakan pendekatan yuridis empiris. Hasil penelitian mendapatkan bahwa faktor penyebab terjadinya kasus kekerasan terhadap anak di masa pandemi Covid-19 yaitu dikarenakan faktor ketidaksiapan orangtua dalam situasi ini, faktor krisis ekonomi, serta dikarenakan faktor pendidikan yang dilakukan di rumah. Dan tulisan ini juga memberikan solusi pencegahan kekerasan terhadap anak di masa pandemi Covid-19 dengan cara kegiatan sosialisasi yang dilakukan peneliti di Desa Brengkok.
\end{abstract}

Kata Kunci: Implementasi, Pencegahan Kekerasan anak, Pandemi Covid-19.

\begin{abstract}
:
The purpose of this study is to determine the factors that cause violence against children during the Covid-19 pandemic and how to prevent and implement it based on lawo number 35 of 2014. This study uses descriptive qualitative research methods with the type of field research that uses empirical juridical approach. The results of the study found that the factors that causedcases of violence against children during the Covid-19 pandemic were due to the unpreparedness off parents in this situation, the economic crisis, and the education factor carried out at home. And this article also provides a solution to prevent violence against children during the Covid-19pandemic by means of socialization activities carried out by researchers in Brengkok Village.
\end{abstract}

Keywords: Implementation, Prevention of Child Violence, Covid-19 Pandemic.

\section{PENDAHULUAN}

Pandemi Covid-19 menyebabkan dunia dalam situasi krisis hampir di seluruh aspek kehidupan. Bukan hanya pada permasalahan ekonomi saja, tetapi permasalahan lingkungan, kesehatan, maupun psikis seseorang juga merupakan salah satu yang terdampak dari akibat adanya pandemi Covid-19.

FENOMENA, Vol. 20 No. 2 (Juli - Desember 2021) | 311 


\section{Implementasi Undang-Undang Nomor 35 Tahun 2014 Tentang}

Anak merupakan salah satu kelompok yang rentan terhadap penularan virus Covid-19. Namun, tidak bisa dipungkiri bahwa untuk tetap berada di rumah juga tidak sepenuhnya aman untuk anak. Permasalahan kasus kekerasan pada anak yang dilakukan oleh seseorang di dalam lingkup rumah tangga sering sekali kita jumpai. Di Indonesia sendiri setiap tahunnya kasus kekerasan anak selalu bertambah. Jumlah peristiwa kekerasan yang dilaporkan kepada Kementerian Pemberdayaan Perempuan dan Perlindungan Anak (KPPPA) pada tahun 2018-2019 mengalami kenaikan yang cukup signifikan. ${ }^{1}$

Dengan adanya situasi pandemi virus Covid-19 saat ini tidak menjadikan adanya penurunan terhadap kasus kekerasan pada anak. Justru sebaliknya, data menunjukkan bahwa kekerasan terhadap anak meningkat secara drastis selama pandemi Covid-19. Kekerasan yang dialami anak tidak hanya berupa kekerasan fisik tetapi juga kekerasan mental dan psikis selama berada di rumah. Data mencatat bahwa kasus kekerasan terhadap anak di Indonesia selama periode 11 April 2020 hingga 23 Mei 2021 mencapai 5.697 kasus dengan 6.315 korban (kompas.com). Angka ini meningkat jika dibandingkan dengan data Komisi Perlindungan Anak Indonesia tahun 2019 sebesar 4.369 kasus dan tahun 2018 sebesar 4.885 kasus kekerasan anak (okezone.com).

Dalam Undang-Undang No. 35 Tahun 2014 tentang Perlindungan Anak secara tegas menyatakan bahwa, anak adalah penerus bangsa yang harus dijamin perlindungannya dari segala bentuk kekerasan dan diskriminasi. ${ }^{2}$ Namun fakta di lapangan justru sebaliknya.

Berdasarkan observasi di lapangan penulis menjumpai salah satu contoh kasus permasalahan kekerasan anak dimasa pandemi di desa Brengkok Kabupaten Lamongan ini dikarenakan adanya Pembatasan Sosial Berskala Besar (PSBB) hingga saat ini adanya Pemberlakuan Pembatasan Kegiatan Masyarakat (PPKM) Darurat. Dengan semua pemberlakuan kebijakan pemerintah tersebut, semua kegiatan dilakukan di rumahdan orang tua dituntut untuk membantu pembelajaran anak yang dilakukan di rumah. Sementara tidak semua anggota keluarga siap dengan kondisi ini, apalagi jika orang tua sedang mengalami permasalahan tekanan ekonomi. Maka tidak bisa dipungkiri jika anak akan menjadi korban pelampiasan frustasi dan kemarahan orang tua yang akan mengakibatkan terjadinya kekerasan terhadap anak.

\section{LANDASAN TEORI}

1. Tinjauan Umum Terkait Implementasi

Ada beberapa pendapat para ahli terkait pengertian implementasi diantarannya sebagai berikut:

\footnotetext{
${ }^{1}$ Iin Kandedes, "Kekerasan Terhadap Anak di Masa Pandemi Covid-19," Jurnal Harkat: Media Komunikasi Gender 16, no. 1 (2020): 67-76.

${ }^{2}$ Kemenenteri Hukum dan HAM RI, Undang-Undang Nomor 35 Tabun 2014 Tentang Perlindungan Anak (Indonesia, 2014).
} 
a. Menurut Usman, implementasi adalah bermuara pada aktivitas, aksi, tindakan, atau adanya mekanisme suatu sistem. Implementasi bukan sekedar aktivitas, tetapi suatu kegiatan yang terencana dan untuk mencapai tujuan kegiatan. ${ }^{3}$

b. Menurut Setiawan, implementasi adalah perluasan aktivitas yang saling menyesuaikan proses interaksi antara tujuan dan tindakan untuk mencapainya serta memerlukan jaringan pelaksana, birokrasi yang efektif. ${ }^{4}$

Berdasarkan pendapat para ahli diatas maka dapat disimpulkan bahwa implementasi adalah suatu kegiatan yang terencana, bukan hanya suatu aktifitas dan dilakukan secara sungguh-sungguh berdasarkan acuan norma-norma tertentu untuk mencapai tujuan kegiatan.

2. Tinjauan Umum Terkait Anak

Menurut perundang-undangan yang berlaku di Indonesia, ketentuan batas kedewasaan merupakan tolak ukur pengertian anak, diantaranya adalah sebagai berikut:

a. Anak menurut ketentuan umum Pasal 1 angka 2 Undang-undang Nomor 4 Tahun 1979 tentang Kesejahteraan Anak disebutkan bahwa anak adalah seorang yang belum mencapai umur 21 (dua puluh satu) tahun dan belum kawin. ${ }^{5}$

b. Anak menurut Undang-Undang Nomor 3 Tahun 1997 tentang Pengadilan Anak dinyatakan bahwa anak adalah orang yang dalam perkara anak nakal telah mencapai umur 18 (delapan belas) tahun dan belum pernah kawin. ${ }^{6}$

c. Anak menurut Undang-Undang Nomor 35 Tahun 2014 tentang Perlindungan Anak dinyatakan bahwa anak adalah seorang yang belum berusia 18 (delapan belas) tahun baik anak yang masih berada dalam kandungan. ${ }^{7}$

d. Anak menurut Kitab Undang-undang Hukum Perdata Pasal 330 Kitab Undang-undang Hukum Perdata (KUH Perdata) menyatakan bahwa belum dewasa adalah mereka yang belum mencapai umur genap dua puluh satu tahun, dan tidak lebih dahulu telah kawin. ${ }^{8}$

3. Tinjauan Umum Terkait Kekerasan Anak

a. Pengertian Kekerasan Anak

Ada beberapa pengertian kekerasan anak menurut para ahli diantarannya sebagai berikut:

1) Marzuki Umar Sa’abah: mengemukakan bahwa kekerasan terhadap anak adalah

\footnotetext{
${ }^{3}$ Usman Nurdin, Konteks Implementasi Berbasis Kurikulum (Jakarta: Raja Grafindo Persada, 2002), 70.

4 Setiawan Guntur, Implementasi Dalam Birokrasi Pembangunan (Bandung: Remaja Rosdakarya, 2004), 39.

${ }^{5}$ Kemenenteri Hukum dan HAM RI, Undang-undang Nomor 4 Tahun 1979 tentang Kesejabteraan Anak. (Jakarta,

${ }^{6}$ Kemenenteri Hukum dan HAM RI, Undang-undang Nomor 3 Tabun 1997 tentang Pengadilan Anak. (Indonesia,

${ }^{7}$ Kemenenteri Hukum dan HAM RI, Undang-Undang Nomor 35 Tabun 2014 Tentang Perlindungan Anak.

8 Rany Mangunsong dan Situmeang \& Situmeang Law Firm, Kitab Undang-Undang Hukum Perdata Indonesia (Indonesian Civil Code: Burgerlijk Wetboek Voor Indonesie) (Jakarta: Gramedia Pustaka Utama, 2004), chap. 330.
} 1979). 1997). 


\section{Implementasi Undang-Undang Nomor 35 Tahun 2014 Tentang}

tindakan terhadap anak dengan cara yang disadari ataupun tidak yang berakibat mengganggu, proses tumbuh kembang anak. Sehingga dapat menimbulkan cacat fisik, mental bahkan kematian pada anak.

2) Menurut Straus dan Gelles: kekerasan terhadap anak merupakan pemberian hukuman fisik dengan tujuan agar anak tidak nakal. Kekerasan terhadap anak mengacu pada tindakan meninju, menggigit, memukul, dan usaha menikam anak. ${ }^{10}$

3) Menurut Huraerah: kekerasan terhadap anak merupakan peristiwa pelukaan fisik dan mental yang dilakukan oleh orang tua yang mempunyai tanggung jawab terhadap kesejahteraan anak, yang diindikasikan dengan kerugian dan ancaman terhadap kesehatan dan kesejahteraan anak.

b. Bentuk-Bentuk Kekerasan Pada Anak

Bentuk-bentuk kekerasan terhadap anak menurut Mieke Diah Anjar Yanti adalah sebagai berikut: ${ }^{11}$

1) Kekerasan Fisik

Tindakan yang menyebabkan rasa sakit atau potensi menyebabkan sakit yang dilakukan oleh orang lain, dapat terjadi sekali atau berulang kali seperti dipukul, ditendang, ditempeleng, dijewer, dicubit, dilempar dengan benda keras, dijemur di bawah terik sinar matahari.

2) Kekerasan psikis

Segala sesuatu yang dapat menyebabkan terhambatnya perkembangan psikologis anak seperti kata-kata yang mengancam, menakut-nakuti, berkata-kata kasar, mengolokolok, perlakuan diskriminatif, membatasi kegiatan sosial dan kreasi.

3) Kekerasan Seksual

Keterlibatan anak dalam kegiatan seksual yang tidak dipahaminya seperti perlakuan tidak senonoh dari orang lain, kegiatan yang menjurus pada pornografi, perkataan-perkataan porno, perbuatan cabul dan persetubuhan pada anak-anak yang dilakukan orang lain dengan tanpa tanggung jawab, tingkatan mendorong atau memaksa anak terlibat dalam kegiatan seksual yang melanggar hukum seperti dilibatkan pada kegiatan prostitusi.

${ }_{9}^{9}$ Marzuki Umar Sa’abah, Perilaku Seks Menyimpang dan Seksualitas Kontemporer Umat Islam (Yogyakarta: UII Press, 2006), 91.

${ }^{10}$ Jan E. Stets dan Murray A. Straus, "The Marriage License as a Hitting License: A Comparison of Assaults in Dating, Cohabiting, and Married Couples," Journal of Family Violence 4, no. 2 (Juni 1989): 161-180; Richard J. Gelles, "Violence in the Family: A Review of Research in the Seventies," Journal of Marriage and the Family 42, no. 4 (November 1980): 873; Barbara Krahe, Perilaku Agresif: Buku Panduan Psikologi Sosial, trans. Helly Prajitno Soetjipto, Sri Mulyani Soetjipto, dan Kamdani (Yogyakarta: Pustaka Pelajar, 2005).

${ }_{11}$ Mieke Diah Anjar Yanit dan dkk., Model Sistem Monitoring dan Pelaporan Anak dan Perempuan Korban Kekerasan (Jawa Tengah: BAPENAS, 2006), 9-11. 
4) Kekerasan ekonomi (eksploitasi komersial)

Penggunaan anak untuk bekerja dan kegiatan lainnya demi kebutuhan orang tuanya atau orang lain seperti menyuruh anak bekerja secara berlebihan, menjerumuskan anak kepada dunia prostitusi untuk kepentingan ekonomi.

5) Penelantaran Anak

Adalah bentuk ketidakpedulian orang tua, orang yang bertanggung jawab atasanak pada kebutuhan mereka seperti pengabaian pada kesehatan anak, pengabaian dan penelantaran pada pendidikan anak, pengabaian pada pengembangan emosi, penelantaran pada pemenuhan gizi, pengabaian dan penelantaran pada penyediaan perumahan, atau pengabaian pada kondisi keamanan dan kenyamanan.

c. Faktor-faktor Penyebab Terjadinya Kekerasan Pada Anak

Kekerasan terhadap anak umumnya disebabkan oleh faktor internal (diri siswa) maupun eksternal (keluarga dan masyarakat) diantarannya sebagai berikut: ${ }^{12}$

1) Anak mengalami cacat tubuh: seperti retardasi mental, gangguan tingkah laku, autisme, anak terlalu lugu, memiliki temperamen lemah, ketidaktahuan anak akan hak-haknya.

2) Kemiskinan keluarga: orang tua menganggur, penghasilan tidak cukup, banyak anak.

3) Keluarga tunggal anak keluarga pecah (broken home): misalnya perceraian, ketiadaan ibu untuk jangka panjang atau keluarga tanpa ayah dan ibu tidak mampu memenuhi kebutuhan anak secara ekonomi.

4) Keluarga yang belum matang secara psikologi: ketidaktahuan mendidik anak, harapan orang tua yang tidak realistis, anak yang tidak diinginkan, anak yang lahir di luar nikah.

5) Penyakit parah atau gangguan mental pada salah satu kedua orang tua: misalnya tidak mampu merawat dan mengasuh anak karena gangguan emosional dan depresi.

6) Sejarah penelantaran anak: Orang tua yang semasa kecilnya mengalami perlakuan salah cenderung memperlakukan salah anak-anaknya.

7) Kondisi lingkungan yang buruk: permukiman yang kumuh, tergusurnya tempat bermain anak, sikap acuh tak acuh terhadap tindakan eksploitasi, pandangan terhadap nilai anak yang terlalu rendah, meningkatnya faham ekonomi upah, lemahnya perangkat hukum, tidak ada mekanisme kontrol sosial yang stabil.

\section{METODE PENELITIAN}

1. Jenis Penelitian

Jenis penelitian yang digunakan dalam penelitian ini adalah penelitian lapangan (field research), yaitu penelitian yang digunakan untuk memperjelas kesesuaian antara teori dan praktik.

${ }^{12}$ Abu Huraerah, Kekerasan Terhadap Anak (Bandung: Nuansa Cendekia, 2012), 70. 
Sehubungan dengan objek yang akan diteliti, penulis memilih lokasi penelitian di Desa Brengkok Kabupaten Lamongan. Dalam rangka pendekatan pada obyek yang diteliti serta pokok permasalahan, maka spesifikasi pada penelitian ini menggunakan pendekatan yuridis empiris. Penelitian yang menggunakan pendekatan yuridis empiris yaitu penelitian yang menekankan pada fakta-fakta yang terjadi di lapangan mengenai "Implementasi Undang-undang No. 35 tahun 2014 tentang Perlindungan Anak Terhadap Pencegahan Kekerasan Pada Anak di Masa Pandemi Covid-19”.

2. Data dan Sumber Data

Sumber data dalam penelitian ini adalah sebagai berikut:

a. Sumber data Primer, yaitu data yang diperoleh peneliti melalui penelitian lapangan dengan pihak-pihak yang terkait dengan penelitian ini.

b. Sumber data Sekunder, yaitu data yang diperoleh peneliti dari pengumpulan studi kepustakaan yaitu berupa undang-undang, literatur, dan dokumen-dokumen yang relevan dengan materi penulisan serta buku-buku dan jurnal yang ada hubunganya dengan penelitian ini.

3. Teknik Pengumpulan Data

Dalam memperoleh data secara komprehensif, serta memperhatikan relevansi datadengan fokus dan tujuan penelitian, maka dalam teknik pengumpulan data penelitian ini yaitu sebagai berikut:

a. Observasi

Observasi adalah teknik pengumpulan data yang dilakukan dengan cara, penyelidik mengadakan pengamatan secara langsung (tanpa alat) terhadap gejala-gejala subjek yang diselidiki. $^{13}$

b. Wawancara

Wawancara adalah proses tanya jawab antara pewawancara dengan informan guna memperoleh informasi yang lebih terperinci sesuai tujuan penelitian. ${ }^{14}$

c. Kepustakaan

Data kepustakaan adalah data yang diambil dari buku, majalah, koran, jurnal, dan skripsi. Kepustakaan tersebut didasarkan pada teori-teori yang jelas. Studi utamanya adalah mencari dasar pijakan untuk memperoleh landasan teori.

d. Dokumentasi

${ }^{13}$ Mardalis, Metode Penelitian Suatu Pendekatan Proposal (Jakarta: Bumi Aksara, 2008), 74.

14 Zainal Arifin, Penelitian Pendidikan: Metode Penelitian Kualitatif (Bandung: Remaja Rosdakarya, 2012), 170. 
Dokumentasi merupakan teknik pengumpulan data yang tidak langsung ditujukan kepada subjek penelitian. Dokumen dapat berupa buku harian, surat pribadi, laporan, notulen rapat, catatan kasus dalam pekerjaan sosial dan dokumen lainnya. ${ }^{15}$

4. Metode Analisa Data

Metode analisa data adalah proses mencari dan mengatur secara sistematis. Kegiatan analisis data ini dilakukan dengan menelaah data, menata, membagi menjadi satuan-satuan sehingga dapat dikelola yang akhirnya dapat ditemukan makna yang sebenarnya dengan rumusan masalah. ${ }^{16}$ Penerapan metode analisa data ini yaitu dengan cara mendeskripsikan dan menjabarkan terkait Implementasi UU No. 35 Tahun 2014 terhadap Pencegahan Kekerasan Anak di masa Pandemi Covid-19 dengan langkah-langkah sebagai berikut:

a. Reduksi Data

Suatu bentuk analisis guna mempertajam, memilih dan memilah data yang telah diperoleh dengan jumlah yang banyak, menfokuskan data pada hal-hal yang penting, membuang serta menyusun data dalam suatu cara dimana kesimpulan akhir dapat digambarkan dan diverifikasikan. ${ }^{17}$

b. Penyajian Data

Penyajian data adalah mengolah data yang masih mentah atau setengah jadi yang sudah dalam bentuk tulisan dan memliki alur yang cukup jelas sehingga memudahkan dalam penarikan kesimpualan. Penyajian data ini berisi tentang informasi yang dihasilkan oleh peneliti dari kegiatan pengolahan atau analisis data yang telah dikumpulkan. Dalam hal ini penyajian data bisa dilakukan dengan melalui uraian singkat. Jadi dalam penyajian data untuk mencari informasi ini kami menggunakan beberapa jurnal dan buku.

c. Penarikan Kesimpulan

Penarikan Kesimpulan adalah kegiatan menyimpulkan makna yang muncul dari data yang diuji kebenarannya, kekokohan dan kecocokan. Penarikan kesimpulan adalah langkah terakhir yang dilakukan penelitian dalam menganalisis data secara terus-menerus baik pada saat pengumpulan data dan setelah pengumpulan data.

\section{HASIL PENELITIAN DAN PEMBAHASAN}

1. Faktor Penyebab Terjadinya Kekerasan Pada Anak di Masa Pandemi Covid-19 di Desa Brengkok

\footnotetext{
15 Irawan Suhartono, Metode Penelitian Sosial: Suatu Teknik Penelitian Bidang Kesejabteraan Sosial dan Ilmu Sosial lainnya (Bandung: Remaja Rosdakarya, 1995), 70.

${ }^{16}$ Mukhamad Saekan, Metodologi Penelitian Kualitatif (Kudus: Nora Media Enterprise, 2010), 91.

17 Hengki Wijaya, Analisis Data Kualitatif Imu Pendidikan Teologi (Makasar: Sekolah Tinggi Theologia Jaffray Makassar, 2018), 56-57.
}

FENOMENA, Vol. 20 No. 2 (Juli - Desember 2021) | 317 


\section{Implementasi Undang-Undang Nomor 35 Tahun 2014 Tentang}

Sejak munculnya pandemi virus Covid-19, pemerintah mengeluarkan berbagai kebijakan. Mulai dari kebijakan Pembatasan Sosial Berskala Besar (PSBB), sampai dengan saat ini yaitu kebijakan Pemberlakuan Pembatasan Kegiatan Masyarakat (PPKM) Darurat, sebagai upaya memutus mata rantai penularan virus Covid-19. Dari semua kebijakan tersebut, berakibat semua kegiatan masyarakat dibatasi serta tidak diperbolehkannya masyarakat berada dalam kerumunan yang mengakibatkan kegiatan belajar, bekerja, dan beribadah dilakukan dari rumah. Konsekuensi dari kebijakan ini adalah meningkatnya intensitas anak dan orang tua untuk berinteraksi secara langsung setiap harinya.

Berikut merupakan faktor penyebab terjadinya kekerasan terhadap anak di masa pandemi Covid-19, sebagai berikut:

a. Faktor Ketidaksiapan Orangtua

Dalam hal ini penulis mewawancarai salah satu Ibu di Desa Brengkok yang berinisial SM (39), "Sebenarnya saya kesulitan untuk beradaptasi dengan kondisi saat ini, yang melakukan kegiatan apapun dibatasi. Ditambah anak yang kadang susab untuk diatur dan tidak mau berdiam diri di rumah"

Dari hasil wawancara bersama Ibu SM tersebut, salah satu faktor terjadinya kekerasan terhadap anak yaitu dikarenakan adanya perubahan rutinitas dan ketidaksiapan orang tua dan anak dalam beradaptasi dengan kondisi saat ini. Rasa jenuh selalu berada di rumah dan terbatasnya interaksi sosial dengan masyarakat menjadi pemicu awal terjadinya konflik antar anggota keluarga yang berakibat padaterjadinya kekerasan terhadap anak.

\section{b. Faktor Krisis Ekonomi}

Pembatasan aktivitas di ruang publik juga berdampak pada pendapatan masyarakat, terutama ekonomi menengah ke bawah. Tekanan ekonomi semakin diperparah dengan kasus Pemutusan Hubungan Kerja (PHK) akibat pandemi Covid-19. Sementara desakan ekonomi pada masa pandemi Covid-19 cenderung naik yang berpengaruh pada kenaikan harga barang termasuk kebutuhan pokok. Perubahan kondisi ekonomi keluarga inilah yang semakin memperburuk psikologis orang tua. Dan dalam kondisi ini anak akan berada pada posisi korban dari luapan emosi dan frustasi orang tua yang mengakibatkan adanya kekerasan terhadap anak sedangkan kondisi anak tidak berdaya untuk melakukan perlawanan.

c. Faktor Pendidikan

Pandemi Covid-19 telah memaksa sistem pembelajaran di sekolah dilakukan secara daring (online). Pembelajaran daring menjadi hal baru bagi anak dan orang tua bahkan bagi dunia pendidikan nasional. Tidak semua orang tua mempunyai pengetahuan yang cukup untuk memahami skema pembelajaran tersebut, sedangkan orang tua dituntut mendampingi 
anak selama kegiatan pembelajaran daring berlangsung. Demikian juga fasilitas pendukung pembelajaran daring seperti gadget, kuota internet, dan sinyal juga dirasakan memberatkan orang tua di tengah tekanan ekonomi akibat pandemi Covid-19. Akibatnya ketika anak dinilai kurang mampu menguasai proses pembelajaran daring, orang tua tidak mampu mengendalikan emosi. Dan dari sinilah peluang terjadinya kekerasan terhadap anak akan muncul.

Seperti dari hasil pengamatan peneliti di Desa Brengkok, Permasalahan kekerasan terhadap anak yang sering terjadi akibat faktor pembelajaran daring yaituketika, "Anak tidak. mampu menguasai proses pembelajaran daring yang dilakukandi rumah, sedangkan orang tua dirasa sudah membiayai pembelajaran daringmeskipun dalam keterbatasan ekonomi”. Hal inilah yang menjadi salah satu pemicu kemarahan dan emosi orang tua kepada anak, yang akan berakibat terjadinya kekerasan terhadap anak dikarenakan faktor pendidikan.

\section{Implementasi UU No. 35 Tahun 2014 Terhadap Pencegahan Kekerasan Anak di Masa}

\section{Pandemi di Desa Brengkok}

Berdasarkan Undang-Undang Nomor 35 Tahun 2014 Tentang Perlindungan Anak telah disebutkan bahwa, "Setiap anak berhak atas kelangsungan hidup, tumbuh dan berkembang serta berhak atas perlindungan dari kekerasan dan diskriminasi”. Dalam Pasal 1 ayat (2) juga dijelaskan bahwa, "Perlindungan anak adalah segala kegiatan untuk menjamin dan melindungi anak dan hak-haknya agar tetap hidup, tumbuh, berkembang, dan berpartisipasi secara optimal sesuai dengan harkat dan martabat kemanusiaan, serta mendapat perlindungan dari segala macam bentuk kekerasan dan diskriminasi". ${ }^{18}$

Meskipun dalam Undang-Undang diatas sudah dijelaskan dengan tegas, namun pada fakta kenyataanya masih banyak terjadi kasus kekerasan terhadap anak di masa pandemi Covid-19 saat ini, dalam hal ini maka penulis melakukan sosialisasi kecil terhadap ibu-ibu di Desa Brengkok untuk memberikan sedikit pemahaman terkait pencegahan kekerasan anak di masa pandemi Covid-19 di desa Brengkok berdasarkan Undang-Undang No. 35 Tahun 2014.

Pencegahan yang dimaksud adalah berupa usaha-usaha yang dilakukan agar perbuatan kejahatan apapun tidak sempat dilakukan, dengan pengertian bahwa perlindungan tersebut adalah dengan menciptakan kondisi yang baik agar anak dapat tumbuh dan berkembang dengan baik. Karena pada dasarnya suatu pencegahan adalah lebih baik daripada melakukan perbaikan, penyembuhan maupun penindakan. Upaya pencegahan kekerasan terhadap anak memang bukanlah hal yang mudah, namun tetap harus dilakukan untuk melindungi anak beserta hak-

${ }^{18}$ Kemenenteri Hukum dan HAM RI, Undang-Undang Nomor 35 Tabun 2014 Tentang Perlindungan Anak, chap. 1 Ayat 2. 


\section{Implementasi Undang-Undang Nomor 35 Tahun 2014 Tentang}

haknya. Berikut ini merupakan materi kegiatan sosialisasi yang dilakukan peneliti kepada ibu-ibu di Desa Brengkok:

a. Pencegahan kekerasan terhadap anak harus dimulai dari memahamkan kepada masyarakat bahwa keluarga sebagai lingkungan terdekat anak.

Banyak kasus kekerasan terhadap anak justru dilakukan oleh anggota keluarga. Oleh karena itu, penguatan peran dan fungsi keluarga perlu dilakukan. Keluarga dapat mulai mengatur ulang pengelolaan sumber daya yang dimiliki baik fisik maupun nonfisik serta masalah yang dihadapi keluarga pada masa pandemi Covid-19. Selanjutnya perlu diciptakan iklim yang kondusif dalam keluarga dengan dukungan, komitmen, dan komunikasi anggota keluarga sehingga memperkuat kapasitas keluarga dalam menghadapi pandemi Covid-19.

b. Meningkatkan pengetahuan orang tua dalam hal pengasuhan anak.

Pada masa pandemi Covid-19, orang tua perlu menyesuaikan pengasuhan anak dengan kondisi tersebut. Misalnya dengan meningkatkan literasi terkait pengasuhan anak khususnya pada masa Covid-19, serta berdiskusi dengan komunitasnya atau mengikuti webinar terkait. Dengan demikian orang tua lebih mudah beradaptasi dengan pengasuhan anak selama pandemi Covid-19. Orang tua dapat mulai mendiskusikan terlebih dahulu mengenai aturan-aturan di rumah. Selanjutnya orang tua memposisikan diri sebagai guru, pengasuh sekaligus sahabat selama mendampingi anak di rumah sehingga tercipta pola pengasuhan anak tanpa kekerasan.

c. Memperkuat komunikasi dan kerja sama antara orang tua dengan sekolah selama mendampingi anak belajar di rumah.

Selama pandemi Covid-19, pembelajaran daring menjadi pilihan rasional dalam pendidikan. Namun demikian, pembelajaran daring menuntut kesiapan kedua belah pihak baik sekolah maupun peserta didik. Sekolah harus mampu bekerja samasecara intens dengan orang tua selama proses pembelajaran daring untuk meminimalkan dampak negatif pembelajaran daring bagi anak. Sekolah perlu menyosialisasikan kepada orang tua pentingnya mendidik anak tanpa kekerasan. Dalam hal ini, Kementerian Pendidikan dan Kebudayaan serta Kementerian Komunikasi dan Informasi dapat mendukung dengan melakukan sosialisasi mendidik anak tanpa kekerasan melalui saluran belajar jarak jauh, termasuk melalui berbagai media. Dengan demikian orang tua lebih memahami tentang kebutuhan anak, hak anak, dan perlindungan anak.

d. Perbaikan ekonomi keluarga

Perbaikan ekonomi keluarga dapat dimulai dengan pemberdayaan ekonomi keluarga. Pemberdayaan ekonomi keluarga meliputi penataan pola pikir keluarga untuk dapat 
mengelola keuangan dengan baik, menciptakan produk dengan modal dari sumber pembiayaan seperti koperasi agar memudahkan dalam hal persyaratan, dan membangun jaringan pemasaran melalui teknologi digital.

e. Penguatan peran dari berbagai lembaga keagamaan dan lembaga masyarakat di tingkat lokal

Lembaga tersebut berperan melakukan sosialisasi tentang perlindungan hak anak di kalangan masyarakat. Metode pendekatan dan komunikasi yang didasarkan pada nilai, norma, dan budaya masyarakat akan lebih mudah diterima oleh masyarakat. Setelah sosialisasi selanjutnya bisa dilakukan gerakan Perlindungan Anak Terpadu Berbasis Masyarakat (PATBM). Gerakan PATBM merupakan inisiatif masyarakat untuk mencegah kekerasan terhadap anak dengan membangun kesadaran masyarakat sehingga terjadi perubahan pemahaman, sikap, dan perilaku yang melindungi anak.

\section{SIMPULAN}

Faktor penyebab terjadinya kekerasan terhadap anak di masa pandemi Covid-19 yaitu sebagai berikut: faktor ketidaksiapan orangtua terhadap situasi pandemi saat ini yang semuanya butuh adaptasi, faktor krisis ekonomi dimana ekonomi keluarga berada pada tingkat ekonomi yang rendah, dan faktor pendidikan yaitu dengan pemberlakuan kegiatan belajar di rumah. Semua itu merupakan faktor yang memicu terjadinya kekerasan terhadap anak dikarenakan faktor pendidikan.

Implementasi upaya pencegahan kekerasan terhadap anak berdasarkan UU No. 35Tahun 2014, yaitu dengan cara: a) Pencegahan kekerasan terhadap anak harus dimulai dari memahamkan kepada masyarakat bahwa keluarga sebagai lingkungan terdekat anak; b) Meningkatkan pengetahuan orang tua dalam hal pengasuhan anak; c) Memperkuat komunikasi dan kerja sama antara orang tua dengan sekolah selama mendampingi anak belajar di rumah; d) Perbaikan ekonomi keluarga; dan e) Penguatan peran dari berbagai lembaga keagamaan dan lembaga masyarakat di tingkat lokal.

Dengan telah dilakukannya kegiatan sosialisasi pencegahan kekerasan terhadap anak, penulis berharap dapat memberikan pemahaman kepada masyarakat khususnya orangtua untuk lebih memperhatikan anak dan tidak menjadikan anak sebagai pelampiasan amarah dan korban kekerasan. Khususnya di situasi pandemi saat ini, semua kegiatan yang dibatasi dan sebagian pembelajaran anak yang dilakukan di rumah. Mengharuskan orangtua mampu beradaptasi dan lebih sabar lagi dalam membimbing pembelajaran anak karena kondisi seperti ini juga sebenarnya menyulitkan untuk anak itu sendiri. 


\section{DAFTAR PUSTAKA}

Arifin, Zainal. Penelitian Pendidikan: Metode Penelitian Kualitatif. Bandung: Remaja Rosdakarya, 2012.

Diah Anjar Yanit, Mieke, dan dkk. Model Sistem Monitoring dan Pelaporan Anak dan Perempuan Korban Kekerasan. Jawa Tengah: BAPENAS, 2006.

Gelles, Richard J. "Violence in the Family: A Review of Research in the Seventies." Journal of Marriage and the Family 42, no. 4 (November 1980): 873.

Guntur, Setiawan. Implementasi Dalam Birokrasi Pembangunan. Bandung: Remaja Rosdakarya, 2004.

Hengki Wijaya. Analisis Data Kualitatif Ilmu Pendidikan Teologi. Makasar: Sekolah Tinggi Theologia Jaffray Makassar, 2018.

Huraerah, Abu. Kekerasan Terhadap Anak. Bandung: Nuansa Cendekia, 2012.

Kandedes, Iin. "Kekerasan Terhadap Anak di Masa Pandemi Covid-19." Jurnal Harkat: Media Komunikasi Gender 16, no. 1 (2020): 67-76.

Kemenenteri Hukum dan HAM RI. Undang-undang Nomor 3 Tahun 1997 tentang Pengadilan Anak. Indonesia, 1997.

—. Undang-Undang Nomor 35 Tahun 2014 Tentang Perlindungan Anak. Indonesia, 2014.

—. Undang-undang Nomor 4 Tabun 1979 tentang Kesejabteraan Anak. Jakarta, 1979.

Krahe, Barbara. Perilaku Agresif: Buku Panduan Psikologi Sosial. Diterjemahkan oleh Helly Prajitno Soetjipto, Sri Mulyani Soetjipto, dan Kamdani. Yogyakarta: Pustaka Pelajar, 2005.

Mangunsong, Rany, dan Situmeang \& Situmeang Law Firm. Kitab Undang-Undang Hukum Perdata Indonesia (Indonesian Civil Code: Burgerlijk Wetboek Voor Indonesie). Jakarta: Gramedia Pustaka Utama, 2004.

Mardalis. Metode Penelitian Suatu Pendekatan Proposal. Jakarta: Bumi Aksara, 2008.

Nurdin, Usman. Konteks Implementasi Berbasis Kurikulum. Jakarta: Raja Grafindo Persada, 2002.

Sa'abah, Marzuki Umar. Perilaku Seks Menyimpang dan Seksualitas Kontemporer Umat Islam. Yogyakarta: UII Press, 2006.

Saekan, Mukhamad. Metodologi Penelitian Kualitatif. Kudus: Nora Media Enterprise, 2010.

Stets, Jan E., dan Murray A. Straus. "The Marriage License as a Hitting License: A Comparison of Assaults in Dating, Cohabiting, and Married Couples." Journal of Family Violence 4, no. 2 (Juni 1989): 161-180.

Suhartono, Irawan. Metode Penelitian Sosial: Suatu Teknik Penelitian Bidang Kesejabteraan Sosial dan Ilmu Sosial lainnya. Bandung: Remaja Rosdakarya, 1995. 